\title{
The Earliest Foreign Visitors and Their Massive Depopulation of Rapa-iti from 1824 to 1830
}

Rhys Richards

\section{Q OpenEdition \\ 12 Journals}

\section{Electronic version}

URL: http://journals.openedition.org/jso/67

DOI: $10.4000 /$ jso.67

ISSN: $1760-7256$

\section{Publisher}

Société des océanistes

\section{Printed version}

Date of publication: 1 June 2004

Number of pages: 3-10

ISSN: 0300-953x

\section{Electronic reference}

Rhys Richards, «The Earliest Foreign Visitors and Their Massive Depopulation of Rapa-iti from 1824

to 1830 », Journal de la Société des Océanistes [Online], 118 | Année 2004-1, Online since 01 June 2007, connection on 21 April 2019. URL : http://journals.openedition.org/jso/67; DOI : 10.4000/jso.67

\section{(c) Tous droits réservés}




\section{The Earliest Foreign Visitors and Their Massive Depopulation of Rapa-iti from 1824 to 1830}

par

Rhys RICHARDS *

\begin{abstract}
The first foreign visitors to Rapa-iti introduced new technologies and new ideas, but they also introduced foreign diseases and alcohol. Within the six years from 1824 to 1830, over three quarters of the population died. The extinction of the remainder was only narrowly averted. Nevertheless sufficient of the Rapa-iti language survived to indicate that it was unlike the languages of the Austral Islands and Tahiti.
\end{abstract}

KEYWORDS: Rapa-iti, Foreign Visitors, Depopulation, Rapan Language.

A recent chronological review of the scattered references to early visitors to the Austral Islands, south of Tahiti, has uncovered relevant material about Rapa iti, including one or two comments about the Rapan language. Where comments of wider anthropological interest have not been published before, or are little known, these have been included in the following article more or less in full in order to round out the record of what most impressed the earliest visitors.

These foreigners introduced new technologies and a new religion, but they also introduced diseases and alcohol which led to a massive depopulation. Over three quarters of the two thousand or more people on Rapa iti died between 1824 and 1830, and their extinction was only narrowly averted. Nevertheless some of the

\section{RÉSUMÉ}

Les premiers étrangers venus à Rapa-iti ont introduit des idées et des technologies nouvelles, mais aussi des maladies inconnues jusque-là et l'alcool. Dans les six années entre 1824 et 1830, plus des trois quarts de la population décèdent. L'extinction de ceux restant fut évitée de justesse. Quoi qu'il en soit, la langue de Rapaiti survit suffisamment pour indiquer qu'elle n'était pas identique aux langues des Australes et de Tahiti.

MoTS-CLÉs: Rapa-iti, étrangers, dépopulation, langue de Rapa.

Rapan language survived, sufficient to indicate that it was significantly unlike those of the Austral Islands, and Tahitian.

\section{Rapa Discovered by Vancouver in 1791}

On 22 December 1791, Vancouver discovered Rapa or Oparo, and was met offshore by « about thirty single and double canoes », all very narrow, carrying about 300 men. The Rapan men were noisy but uninformative. They brought on board few items except some fish. They had no artefacts except a few fish hooks and lines, and no weapons except « a few spears, a club or two, and two or three indifferent slings for stones ». Apart from a wreath made of a broad long leafed 
green plant, $[t i]$ worn about the waist, they were entirely without clothing. Their bodies were not tattooed or scared. A Hawaiian travelling with Vancouver was unable to talk to them, though even Vancouver recognised the Rapan language as " part of the Great South Sea nation ». [i.e. Polynesian]. Vancouver was not impressed with what he saw of Rapa from the ship:

« No great appearance of plenty, fertility or cultivation, [the land] chiefly clothed with shrubs and dwarf trees. The tops of the six highest hills had the appearance of fortified places. On all of them, we noticed people as if on duty, constantly moving about. » (Vancouver, 1798: vol. 1, 77; Lamb, 1984: vol. 1, 374-375)

\section{Captain Roger Simpson and George Bass 1802}

One of the lesser known traders from Sydney to Tahiti for pork was Captain Roger Simpson who worked for George Bass. It seems they visited the Austral Islands together at least once, and that Simpson also visited alone. Bass did not chose to announce any discoveries, but later Simpson reported that while in the Nautilus in 1802 , he had found an island the natives called Ryvavy. By the accuracy of the latitude and longitude Simpson quoted, this was certainly Raivavae (Sydney Gazette, 29 May 1803) Simpson did not accord this discovery to Bass, and no doubt it was Simpson, not Bass, who named the four rocky islets of Moroiti, southeast of Rapa, as the "Bass Islands» after his friend and patron (Richards ms.). Given that Simpson would have had information of Vancouver's discovery of Rapa, which is only 46 miles away and visible on a clear day, it seems reasonable to assume that as active a trader as Simpson probably visited Rapa as well as the "new » Bass Islands.

\section{Passing Vessels in 1813, 1815 and 1817}

The journal of Stephen Reynolds on the New Hazard, a Salem trader of sea otter skins on the North West Coast of America and at Canton, sighted Rapa on 6 September 1813 en route home and did not stop there (PMB film 220; Howay 1938). The Endeavour of Sydney, en route from New Zealand to the Marquesas, was becalmed off Rapa on 20 July 1815, where the crew « found the Roppa Islanders to be pilferers of anything they could lay their hands on on deck » (Barden, 1999: 23). In January 1817, the LMS missionary Ellis was at Rapa briefly, where he reported thirty canoes of men, without tattoos, and with an exuberant, thieving and unruly disposition (Ellis, 1829: 39-49). These were not shore visits, but would have accustomed the people on Rapa to the existence of other humans and their rare passings.

\section{Bellingshausen and his Russians in June 1820:}

In 1820, two ships of the Russian expedition under Bellingshausen lay off Rapa on 29 and 30 June, but were unable to go on shore. The local Rapans came out to the ships in twenty two narrow unembellished outrigger canoes carrying about 100 men, but no women. They proved to be accustomed to foreign vessels and very eager to trade but inexperienced. Even on the second day they brought only crayfish, taro, poi, dried gourds, cords « earrings, rings and trifles of that sort ». Strong, noisy and enthusiastic thieves, they seemed unarmed and easily intimidated by guns. They were noted as healthy, robust, and unshaven without tattoos. All were described as naked, though one man wore a sash made out of bark, and the others wore a girdle. Fortifications were seen on the hill tops. The Russians had keen eyes for collectable artefacts and curiosities, but apparently collected nothing of note, and one commented that they considered the Rapans' local « domestic culture » to be markedly «less sophisticated » than, for example, the Maori that they had just met in southern New Zealand (Barratt, 1988: 199-221).

\section{First Foreigners Went Ashore in October 1825}

The LMS missionaries believed that the arrival of the first foreigners to land on Rapa occurred only after the crew of tiny 42 ton cutter Snapper, owned by the Tahitian chief Taati, kidnapped two islanders in July 1825, and took them to Tahiti to expose them to the mission, even though " they did not understand much Tahitian » (Davies, 1961: 280). These two Rapans, Paparua and Aitareru. were returned them home safely in September. Captain Shout and the crew of the Snapper had earlier been the first foreigners to set foot on Rapa (Pritchard, 1829; Stutchbury, 1826; Branagan, 1996: 99).

\section{LMS Missionary John Davies in January 1826}

In January 1826, Davies visited for two weeks and landed four Tahitian men and two wives to begin a mission there, noting with massive understatement, that already « there had been a great mortality among the people since they were 
visited by the Snapper $\gg$. Included was the death of « the head chief, Teraau » (Davies, 1961: 280). Davies had joined two Tahiti based sandalwood vessels, Snapper, Captain Samuel Henry, and the Minerva, under Captain Ebrill and owned by Pomare III:

« They had [taken] a few tons of sandalwood, and after being welcomed the whole time, they sailed away after a fortnight. A small quarrel [had arisen] between the men of the Minerva and the Chief of Rapa and his people, once $»$.

According to Elley, who called at Rapa in the Active, a brig owned by Richard Charlton, the English Consul at Honolulu, many Rapans had been killed, but Davies disputed this. While Davies was on Rapa, the Active had visited again from Tahiti, carrying a Honolulu based merchant, Mr Navarro, who had plans to install a gang of Tuamotuans on Rapa to collect sandalwood under a European named Young from Honolulu.

Davies told Moerenhout however that these missionaries "were not the first strangers who had been seen in the island of Rapa because there was a native man from Mangareva, one of the Gambier Islands, then the only survivor of seven who for several years [sic, months?] had been confined to a raft, exhausted with fatigue and dying of hunger. They had all been [well] received by the inhabitants of Rapa, but, nevertheless, in spite of the distance and the small probability of their refinding their own country, four of them wanted to try to return there, and furnished with provisions which their hosts gave them after they had in vain tried to persuade them to remain, they left with a strong west wind, following the direction east-southeast, in which they believed their island was situated. From that time on there was never any news of them, and there is scarcely any doubt that these Indians (shall I say courageous or rash?) perished as victims of their patriotic devotion. The last survivor of the three others, already very old at the time of the arrival of the missionaries, died about 1829 » (Moerenhout, 1993: 452).

Moerenhout, who visited the Australs in 1834 and possibly also earlier, believed that the European visitors had treated the Rapans « as thieves, savages and barbarians, when in essence they are the most peaceful and gentlest people, sociable and most discreet, who if they have lost some of their primitive virtues, have only too much the right of attributing this fatal loss to the alternation of customs through their mixture with ours » (Moerenhout, 1993: 453).

\section{A Pearl Trader, Samuel Stutchbury, Visited Twice in 1826}

The Pacific Pearl Company's two ships, Sir George Osborne and Rolla sailed directly to Rapa, arriving on $22^{\text {nd }}$ April 1826. On going ashore, the naked natives fled until reassured by a Tahitian missionary living there, Nene, whereupon the Rapans « came out of the bush, with leaves fastened round their middles ». Nene told the visitors that sandal wood, "which he described as being very large and fine, was the only produce of the Island worthy of notice, but three vessels had lately been there and obtained the whole that the Island then produced. We found these vessels to have been the Snapper cutter belonging to a Tahitian chief named Tati; the Minerva brig, Captain Abrill, which had sailed for Otaheite 14 days since, and he also described another vessel which we could not make out [the brigantine Active, Captain Elley] who had left a man named Young on the island $»$.

«The missionary and three others had been brought down by the [Governor] Macquarie brig, which vessel sailed about 14 days ago. They described the people, as they appeared to me, to be very peaceable and docile. They are not at all tattooed, but generally appear well made and pleasant countenances. They do not speak the New Zealand or Tahitian language but something resembling the Marquesan [...]. The natives subsist on taro which is very abundant. They also have the Ti root of which the Tahitians formerly made an intoxicating drink (called $A v a$ ). Rats appeared innumerable and exceeding bold, scarcely getting out of the way of our feet [...]. The native name of the island is Rapa (O'Rapa) [...]».

\section{Stutchbury concluded:}

« there is little doubt but it would answer well to bring down a party, and to land them for a time, to cut Sandal Wood, (the native name Eahi). » (Stutchbury ms.: 88; Branagan, 1996: 71-72)

However these two vessels left after spending only one day with men ashore on Rapa.

Both vessels called at Rapa again on 11 June where $\mathrm{Mr}$ Young informed them that he had been left there six months earlier by the British Consul, Mr Charlton, with some Tuamotu men to cut sandal wood and cure beche de mer, but had secured neither. Young told Stutchbury that the first white man to land on Rapa was Captain Shout in October 1825 in the cutter Snapper owned by the Tahitian chief Tati. This was only eight months earlier, but Young had come there after been told that the Minerva had procured twenty tons of fine sandal wood from Rapa. 
Young told Stutchbury that the Rapans were « very peaceable, living entirely on fish and taro, and that the females remarkably chaste, if a man dies or is driven away from the island in his canoe which sometimes happens as they fish a great distance out to sea, the widow will ascend one of the highest and most precipitous mountains and hurl themselves down, thus voluntarily immolating themselves. When a person dies, they place the body in a rude kind of wicker coffin or basket, and carry it to the top of one of the mountains, the relatives and friends assemble, and lament and cut themselves for many days continuance, after some weeks exposure on the mountain, they will place the body or bones in an old canoe, tow it a considerable way out to sea, then fix on a number of large stones, and let it sink. If it is a chief, they will sometimes bury the body on shore. The generality of the natives go about perfectly naked » (Branagan, 1996: 99-100).

\section{The Cruise of the USN schooner Dolphin in June 1826}

On 26 June 1826 the USN schooner Dolphin stopped at Rapa (Oparo) seeking yams and taro. An Englishman came off from the shore to pilot them into the bay. Ashore there were two mission stations directed by Tahitians who had become the sole local authorities. The Rapa natives wore on their shoulders heavy grass mats weighing ten to fifteen pounds, with another lighter grass mat for their loins. Paulding noted there were a sickly lot, " modest and retiring and they evinced a disposition to have little intercourse with us [...]». Paulding described Rapan houses as "scattered about upon the hills, extremely miserable, long and very narrow, about three or four feet high, so that when one entered them, it was necessary to go down on hands and knees ».

The Englishman living ashore was « in charge of a party which had been left there by the English Consul at the Sandwich Islands to collect beach la mar, a valuable article of commerce at Canton. The collection of sandalwood was also to be an object of their attention; but they told us that both were scarce and difficult to obtain a statement we considered of doubtful veracity ». After only a day and a half, the $\mathrm{Dol}$ phin departed for South America (Paulding, 1831: 248-255).

\section{Two American Whaleships Loper and Lima in July 1826}

The log book of the whaleship Loper of Nantucket, Captain Obed Starbuck, records she was at Tubuai on 13 June 1826 when they "saw the schooner Dolphin beating in ", and was at Rapa on 4 July 1826 when they « took up our anchor and came out of Parpolia harbour with a good recruit, [provisions, not crew] bound home ». The Loper then parted company with the Lima of Nantucket, out 18 months under Captain Abraham Swain, who was then "bound to the Line to fill up » (Log of the Loper, SF Museum, PMB 859; Starbuck, 1878: 250). Some whaleships followed in the 1830s and 1840s but only briefly and at erratic intervals, so their contribution should not be over emphasised.

\section{Hugh Cuming, Private Naturalist, in May 1828:}

Hugh Cuming, 1791-1865, was a successful British trader to South America who accumulated sufficient funds to purchase a vessel in order to indulge his passion for scientific collecting. $\mathrm{He}$ collected first in the South Pacific, then returned to London in 1832 where he was elected to the Linnaean Society. He then set out again on a protracted world cruise collecting extensively, especially in the Philippines. His personal journal of the earlier voyage, now in the Mitchell Library in Sydney, has not been published except for his comments on his visit to Easter Island (Cuming ms.).

Hugh Cuming arrived off Oparo or Rapa Island on 17 May 1828, the winter season there. They had difficulty getting a pilot « from their language differing from all the other islands we had visited $»$. Finally they used a 14 year old boy, the son of one of the resident missionaries from Tahiti, who showed them the route taken before by the U S schooner Dolphin two years earlier. Once on shore, Cuming observed that « the language, manner and customs differ materially from the inhabitants of the Society Islands, of which they had not any knowledge until the arrival of the native teachers from Otaheite, nor had they knowledge of other islands than a canoe had drifted on the isle about sixty years ago since with two young men in her, the rest having died. They could not understand them at first. The last of those men died about five years since, having married and has left several children who are from appearance about 50 to 55 years of age. They could not recall the name of 
the island their father came from. The canoe was about 25 feet long and much broader than those of the island.

« The dress of the natives is singular. It consists of two pieces the size and shape of a very large door mat, thickly thrumbed. One of those they fasten around the neck which reaches the loins. The other is made fast to the loins so that the upper one covers the lower one a few inches. These species of cloaks are very heavy, are made of a large bush with a rind taken off, woven by hand with the leaves of the Te Plant split in fine threads, the ends or thrumbs lay one over another about six inches long and very thick by which means they can withstand the rain for a month and not get wet. Old and young of all ages and sexes had not any other dress previous to the arrival of the missionaries. Since that period they have made a small alteration on the Sabbath, that is to say those that had the good fortune to possess any article that they could barter for a piece of cotton cloth to wrap around their loins after the fashion of Otaheite. The above dress gives the people a most grotesque appearance, particularly when they are squatting on their hams, a favourite posture for them when at leisure, which causes the upper cloak to raise itself a little above the neck, and leaves half the head to be seen [...]. [Their] mats are [not very] serviceable in protecting them from the cold and heavy rains that prevail in the winter season. Their summer dress is exactly the same form as the one before mentioned, only it is made entirely from the leaves of the Te plant finely drawn into threads and much longer than the winter dress, yet it is not above half the weight. This dress makes them appear like giants in body but not in height. »

« The men are tall, well made, robust, rather coarse featured, very dark complexion. The females slender, fine figures, pretty round faces, good teeth, lively expressive countenances. Both sexes are kind, obliging, generous and affable, their good nature and innocency [sic] appearing on every occasion. »

« The language of the islanders without doubt had the same [distant] origin with those of the Society Islands. From the length of time without intercourse, and the many corruptions that have taken place at each place, particularly from the circumstance of a chief having a son born to him, and the father giving the child a name of anything known such as a bird or a fish, a plant, a tree, a shell, a place in fact whatever he chooses to call the child, the article giving name to the child must be altered and nevermore called by its original name. These people not having a knowledge of means to record the ancient names, has been one of the principal causes why the inhabitants of an island proceeding from the same stock, should differ so much from the other. »

« Since native missionaries from Otaheite have resided here somewhat about four years, they have taught the natives to read and write in the reformed language of the Society Islands. Some of them have made great progress, principally the youths of both sexes. The grown up people as yet have made but little progress in so much I could not comprehend them at times when speaking of the natural productions of the island. »

« Previous to the arrival of the native teachers, they had but imperfect ideas of a God, not having idols or morai's of any description. They believe an evil spirit came and killed their friends and relatives when he was angry with them, and that the Evil Spirit had been once a chief of the island, and from his bad conduct, the inhabitants had killed him, and that he came at certain seasons and killed their friends for Revenge. "

«The native teachers have built a church [and new villages]. These houses are built in long rows of 12 to 14 , only parted from its neighbour by a mat. The natives do not like this plan. They prefer to live in their ancient sites and dwellings close to their taro grounds. Previous to the arrival of the teachers, perhaps there were not three houses in one place on all the island, but generally single built on the side of a hill facing the harbour or the sea. Those houses was built on a singular form, just the shape of a large wagon having the wheels and the shafts taken off, the roof neatly thatched with rushes of about two feet thick, having a door at each end and three feet high, and two small windows a foot square. The fire place nearly at one end. Each house about 14 feet long and 10 broad. Their houses were impenetrable to cold or rain, but filth and smoke held their sway. »

" On many of the highest points of the most inaccessible mountains, the natives had built strongholds of unwrought stones. What means they had to convey those stones up to their present situation, I never could find, the present generation not having a tradition or the least account of their formation. All they knew respecting them was this: previous to the arrival of the missionaries, there was two chiefs who commanded the island, who often made war on each other. The losing party then had to fly to these mountain fortresses for safety as every male that was taken in the battle or afterwards was slain. The females and children was not molested and was permitted to carry up to their relatives, food until they made peace with the conquerors which was soon effected by the females. Most of those strongholds are square, the walls very thick about ten or eleven feet high with some rugged stones by which they could get up on the platform. On the top was an immense heap of large stones which they threw upon their pursuers if they had the temerity to follow and attack them [...].The mountains I ascended [for three hours each way] appeared to have steps cut in the mount, winding several times around it from its steepness [...]. »

« The [only] weapons of war used by the natives was a lance eighteen feet long, very rudely made, and a short ugly unadorned club. Their fish hooks were made of the roots of trees bent and hardened by fire. Their household furniture consists of a low stool cut out of the solid wood, a stone knife and a few stones to keep the fire together. "

"Their food consisted of fish and tara [...]." (Cuming, ms.) 
Cuming described in detail their building walls and dams to make well watered taro plots, « six to ten ponds from the ravines to the sea, » which he said showed them to be " as good Agriculturalists as any Man in Europe [...]». They had had «neither pigs nor poultry, only a small rat that was never killed. They produced far more tara than the inhabitants could consume [...] sugar cane in wild abundance but small [...]. The $t i$ plant is the most beautiful and grows to a greater size here [...]. The King or Chief is a young man about 20 years of age [...]». Some « 400 or 500 » people came to the shore to farewell them when they left Rapa on 21 May (Cuming, ms.).

\section{A Missionary Visit by Pritchard and Simpson in April 1829}

Most Rapans had decided to adopt Christianity, on the recommendation of the Tahitian teachers, during 1828. Two LMS missionaries, George Pritchard and Alexander Simpson, visited Rapa from 14 to 23 April 1829, this they said «being the first foreign missionaries to ever spend some time among them ». The native teachers from Tahiti taught at four separate «stations », including at Mooduai which the missionaries visited by clambering over the frighteningly steep mountains. They spent their evening there "writing specimens of the Rapan language ». At "Nuhana on the north coast, the King Teraau » led the service. On their travels, the missionaries «saw several Gods which the people had formerly worshipped».

«At Rapa or Oparo », their concluding remarks noted that its population had « reduced since 1826 from 2,000 to 500 , from the same disease which carried off so many at Rivava and Tubuai [...]. The Rapans were accustomed to worship several gods but the principal ones were Paparua and Porere. Paparua was made of the coconut husk, neatly plaited in the form of a cask. Its length is from 2 to 3 inches. To this God they prayed for victory in war, for the recovery of the sick, and for an abundance of turtle in the harbour. Porere was a piece of stone, from 12 to 15 inches long, This they planted in the ground and worshipped at the launching of a Canoe, praying that by that canoe they might obtain plenty of fish, [and] at the building of a new house, praying in it that there might be an abundance of food - and that [there be] much water in the springs. It is also of remark that no sacrifice was offered except fish which at times [as a] present on behalf of those who were sick, that they might return to health $»$.

« Their wars were not so frequent as on some of the neighbouring islands. There still remain several old castles built on the tops of the highest mountains, to which the vanquished repaired, and continued the siege for a very long time. These fortifications appear to have been standing for ages. It is now a long time since they have been used. Some of the oldest people say they have no recollection of war in their time. »

«The Rapan [language] in many respects is different from the Tahitian dialect. From the frequent use of the $\mathrm{K}$ and the ng or gn, it appears more to resemble New Zealand [Maori] or the Marquesans. » (LMS Journals, box 6, edited in the LMS Chronicle: vol.4, 321.)

\section{A Sealing Explorer in 1830}

Rapa did not prove a major centre for sandalwood, though there was still one Englishman, named Davis, living there three years later. Davis was still there when the sealer explorer Isaac Percival in the Rob Roy of Boston called ashore briefly to barter for yams, potatoes, fowls and some goats, on 3, 4 and 5 October 1830. Nine Rapans stayed on board the first night, and on the second night many of the crew stayed on shore with " the King », and " the chief », and " the head mishonary ». ( $\log$ at Mystic, Richards, 1992: 62).

After 1830, more regular contacts ensued with the LMS mission in Tahiti. Though they were never numerous, there were a few more visits by whalers. Three logbooks survive for American whaleships that sighted Rapa in 1832, 1833 and 1837 but they had no contact with the shore. When the two New Bedford whaleships, Coral and Chili, visited on 18 and 19 May 1841, they readily obtained good supplies of « fowls, hogs and other refreshments ", from the friendly locals who said they could have supplied more if only they had been forewarned. This too suggests that whaling visits were few and far between.

\section{An End Note on the Massive Depopulation by 1830}

The original population on Rapa was over 2,000 (Davies, 1961: 331). But in the six years from 1824 to 1830 , Rapa lost about three quarters of its population, mostly from the same wasting disease that had similarly disastrous impact on the Austral Islands. For when $\mathrm{Mr}$ Darling called at Rapa in June 1831, « the population was 357 adults and 243 children, viz 600 in all » (Davies, 1961:281.) By 1836, it had fallen to 
453 , and then the islanders were ravaged by further diseases in the 1840 s, « chiefly consumption, dysentery, worms, and spasms of the stomach and bowels ». Three renegade white residents on Rapa had compounded the islanders'problems by 1836 by teaching them how to distil an alcoholic liquor from a local root.

In 1867, the population had fallen still further to only 120 , in 1946 it was 300 , and now it is over 400 (Hanson, 1970: 30). Extinction of the Rapan people had been averted narrowly, but the combined effect on the original Rapan culture of foreign diseases and the reforms implemented by the resident missionaries, had reduced local historical knowledge to very little at all.

Curiously perhaps what does remain are remnants of the Rapan language. In 1981, Schooling examined the extent to which Tahitian has permeated the Austral Island and Rapan dialects, noting that the people of Pape'ete and Rurutu today find modern Rapan " sufficiently different that neither a speaker of another Australs dialect, nor a Tahitian would understand reo Rapa on first hearing it », though most Rapans today understand, and speak, Tahitian (Schooling, 1981: 22).

Fischer has since examined the Proto Austral dialects, and Rapan, in more depth, using vocabularies compiled in 1864 and 1877 . He concluded that of the several Tahitic dialects in use when the first foreigners arrived at these islands, speakers of Rimataran, Tupaa'ian and Ra'vavaean would have been mutually intelligible, but Rurutuan was probably not, while none of these speakers would have understood Rapan which has Marquesan roots (Fischer, 2000: 99-111).

Stutchbury, Cuming and Pritchard all confirm that the Rapans were not speaking a language readily understood by Tahitians and Tahitian speakers. Both Stutchbury and Pritchard thought the Rapan language was related to Marquesan. Influences from Mangareva could have come long ago from a common root, or perhaps there could have been some more recent borrowings from drift voyagers who reached Rapa, apparently on two separate occasions as mentioned by Stutchbury and Pritchard. Further marked changes could have followed over many generations on Rapa if, as Cuming described very explicitly, there was in operation a form of word suppression and substitution, « name avoidance and linguistic tabooing ». Clark mentioned parallels for such a practice « in Tuamotuan and some other languages » (Clark, 1983: 423). Put in its simplest form, these stray historical snippets support the "standard theory " that
Rapan was a more distant « East Polynesian » language of Marquesan, with some Mangarevan influences. But by far the greatest impression these few remaining snippets convey is the appalling extent to which the records of the former people and culture on Rapa have been lost forever.

\section{BIBLIOGRAPHIE}

BArratt, Glynn, 1988. Russians and the South Pacific 1696-1840. Vol 2., Southern and Eastern Polynesia. Vancouver, University of British Columbia Press.

Branagan , David, 1996. Science in a Sea of Commerce: Seas Trading Venture (1825-1827), by Samuel Stutchbury, Rosebery, NSW, Hippo Books.

The Journal of a South Coral of New Bedford. Mss. Journal 1839-1842, New Bedford Whaling Museum, PMB microfilm 284, frame 356.

Clark, Ross, 1983. Book Review of Langdon and Tryon (q.v.), Journal of the Polynesian Society 93, 3, pp. 419-425.

Cuming, Hugh, Journal of a voyage from Valparaiso to the Society and adjacent islands. 1827-1828, Sydney, Mss. Mitchell Library, Item ZML, A1336, CY reel 194, frames 1-146.

DAVIES, John, 1961. The History of the Tahiti Mission 1799-1830, edited by C.W. Newbury. Cambridge, Hakluyt Society.

Ellis, William, 1831. Polynesian Researches, 2 vol., London, Fisher and Jackson.

EMORY, Kenneth, 1963. East Polynesian Relationships: settlement pattern and time involved as indicated by vocabulary agreements, Journal of the Polynesian Society 72 : 78-100.

FISCHER, Steven, 2000. Preliminary Evidence for Proto Austral, Excluding Rapan, Leo Pasifika. Auckland, Institute of Polynesian Languages and Literature, pp. 99-111.

Hanson, F. Allan, 1970. Rapan Lifeways: Society and History on a Polynesian Island, Boston, Little Brown.

HowAy, F.W., 1938. Voyage of the New Hazard to the North West Coast, Hawaii and China, 1810-1813, by Stephen Reynolds, Peabody Museum, Mass. (reprinted by Ye Galleon Press, Washington 1970).

LANGDON, Robert and Tryon, Darrell, 1983. The Language of Easter Island: Its Development and Eastern Polynesian Relationships, Laie, Hawaii, Institute for Polynesian Studies, Monograph series 4.

Loper of Nantucket, Mss. Journal. 1828, San Francisco Maritime Museum, PMB Microfilm 859.

Marshall, Donald, 1956. The Settlement of Polynesia, Scientific American 95, 2, pp. 58-72.

Moerenhout J..A., 1993. Travels to the Islands of the Pacific Ocean, Maryland. (trans. A.R. Borden.) 
PaUlding, Hiram, 1831. Journal of a Cruise of the US Schooner Dolphin, New York, Carvill.

Pritchard, George and Simpson, Alexander, 1829. Visit to Austral and Marquesas Islands 17 March to 22 May 1829, LMS Journals, Wellington, N.Z., Alexander Turnbull Library, box 6, Item MicroMs-Coll-02 reel Film 5.

Richards, Rhys, 1992. An American Sealing Explorer: Captain Isaac Percival's Search for the Nimrod Islands, 1828-1830, The Log of Mystic Seaport, Mystic, Conn. 44, 3, pp. 59-63.

_, 2004. Austral Islands Paddles: Their Motifs and the Global Search for their Prototype. (submitted for publication.)

Rob Roy of Boston, Journal 1828-1830, G.W.Blunt, Mss., White Library, Mystic Seaport, Mystic, Conn.
Schooling, Stephen, 1981. A linguistic and sociolinguistic survey of French Polynesia, Summer Institute of Linguistics, cyclostyled typescript, $93 \mathrm{p}$.

Starbuck, Alexander, 1878. History of the American Whale Fishery, Washington, U.S. Commission of Fish and Fisheries. (Reprinted 1989 Castle Books, New Jersey).

Stutchbury, Samuel. Observations made during a voyage to New South Wales and the Polynesian Isles in the Pacific Pearl Fishery Company's ships Sir George Osborne and Rolla in the years 1825, 1826 and 1827, Mss., Alexander Turnbull Library, Wellington, N.Z.

Vancouver, George, 1803. A Voyag e of Discovery to the North Pacific Ocean, 6 vols., London (Reprinted 1984 by Hakluyt Society, London, edited by W. Kaye Lamb.) 